\title{
HEINONLINE
}

Citation: 1992 Sup. Ct. Rev. 1231992

Content downloaded/printed from

HeinOnline (http://heinonline.org)

Thu Jul 26 13:40:19 2012

-- Your use of this HeinOnline PDF indicates your acceptance of HeinOnline's Terms and Conditions of the license agreement available at http://heinonline.org/HOL/License

-- The search text of this PDF is generated from uncorrected OCR text.

-- To obtain permission to use this article beyond the scope of your HeinOnline license, please use:

https://www.copyright.com/ccc/basicSearch.do?

\&operation $=$ go\&search Type $=0$

\&lastSearch $=$ simple\&all $=$ on\&titleOrStdNo $=0081-9557$

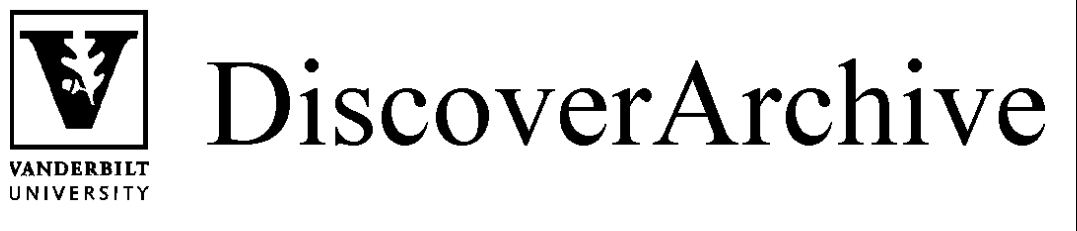

Retrieved from DiscoverArchive,

Vanderbilt University's Institutional Repository

This work was originally published as Suzanna Sherry, Lee v Weisman:

Paradox Redux in 1992 Sup. Ct. Rev. 1231992. 
LEE v WEISMAN:

PARADOX REDUX

For more than two decades, the Supreme Court's Establishment Clause jurisprudence was "at war with" its Free Exercise jurisprudence. $^{1}$ In recent years, however, two major decisionsEmployment Division $v S m i t b^{2}$ and Lee $v$ Weisman ${ }^{3}$ - have effected a significant shift in our religion clause jurisprudence. In this article I will suggest that, considered together, these two decisions have merely replaced one form of incoherence with another. In particular, I will suggest that either decision could be justified alone-and indeed, that either standing alone would be an improvement on the Court's previous religion clause doctrine-but that together they make little sense.

The twenty-year tension between the Court's interpretations of the two religion clauses was especially acute in the context of spe-

Suzanna Sherry is Earl R. Larson Professor of Civil Rights and Civil Liberties Law, University of Minnesota.

AuTHOR's Note: I am very grateful to Daniel Farber, Douglas Laycock, Michael McConnell, and Michael Paulsen for their detailed critical comments on an earlier draft of this essay. They are among the most helpful critiques I have ever received, and the essay is a stronger piece as a result of their comments. As should be apparent from the text, however, their kindness in offering assistance should not be taken as agreement with any of my arguments.

${ }^{1}$ Jesse H. Choper, The Free Exercise Clause: A Structural Overview and an Appraisal of Recent Developments, 27 Wm \& Mary L Rev 943, 947 (1986). See also Jesse H. Choper, Tbe Religion Clauses of the First Amendment: Reconciling tbe Conflict, 41 U Pitt L Rev 673, 674 (1980); Michael W. McConnell, Accommodation of Religion: An Update and a Response to the Critics, 60 Geo Wash L Rev 685, 695 (1992); William P. Marshall, In Defense of Smith and Free Exercise Revisiontism, 58 U Chi L Rev 308, 319-20 (1991); Mark Tushnet, "Of Cburcb and State and the Supreme Court": Kurland Revisited, 1989 Supreme Court Review 373, 377.

2494 US 872 (1990).

${ }^{3} 112$ S Ct 2649 (1992).

(C) 1993 by The University of Chicago. All rights reserved.

$0-226-36247-7 / 93 / 1992-0002 \$ 02.00$ 
cial exemptions for religiously motivated actions. Under the doctrine of Lemon $v$ Kurtzman, ${ }^{4}$ the Court construed the Establishment Clause to forbid the government from preferring religion to nonreligion, or from subsidizing religious activities. Under the doctrine of Sherbert $v$ Verner, however, the Court interpreted the Free Exercise Clause to require government to grant special exemptions to those who opposed general laws on religious grounds. ${ }^{5}$

The problem lay in the Court's attempt to enforce, simultaneously, broad interpretations of both clauses. When a broad reading of one clause directs the government not to promote religion and a broad reading of the other directs it not to hinder religion, it is not possible-especially in a state where government aid and government regulations are pervasive - to read both clauses as imperatives. If the government applies its laws neutrally, it will prohibit some people from practicing their religion. If the government exempts those with religious objections, it will discriminate against those with non-religious objections. Thus a broad interpretation of each clause is in direct conflict with a broad interpretation of the other.

Although commentators have suggested various ways to "reconcile" the two clauses, there are in fact only two solutions to the paradox: one clause or the other must be interpreted very narrowly. The result of a narrow interpretation, however, is to subordinate the core values of that clause to the core values of the other. Either Establishment Clause values must be subordinated to Free Exercise values, or Free Exercise values must be subordinated to Establisl1ment Clause values.

For two short years, the Court resolved the religion clause paradox by adopting the latter of these alternatives, maintaining a broad interpretation of the Establishment Clause while narrowing its interpretation of the Free Exercise Clause. ${ }^{6}$ The Court's most recent decision in this area, however, has undone this effort at reconciliation. In Lee $v$ Weisman the Court abandoned the last vestiges of

${ }^{4} 403$ US 602 (1971).

' 374 US 398 (1963). Sometimes these exemptions took the form of taxpayer supported subsidies and sometimes they constituted merely a discriminatory preference for religion over non-religion, but in either case the required exemptions seemed to run afoul of the Establishment Clause as interpreted by the Court.

${ }^{6}$ See Employment Division v Smith, 494 US 872 (1990), discussed at pp. 150-51. 
Lemon's broad interpretation of the Establishment Clause, leaving little or no meaning to either of the religion clauses. Although this state of affairs may seem preferable to the incoherence of the prior two decades, it is in fact wholly unsatisfactory when evaluated in terms of its consistency with either the Constitution or political theory.

\section{Clauses in Conflict}

In a series of decisions beginning in 1963, the Court held that where a neutral law of general applicability seriously compromised an individual's ability to follow his religious beliefs, the Free Exercise Clause required the government to grant an exemption unless there was a compelling reason not to do so. Although many claims for exemptions were rejected (especially in the waning years of the doctrine), either because the law was found not to impinge on religious beliefs or because the government's interest was found to be compelling, the Court required exemptions in at least four cases $^{7}$ and approved a legislatively granted exemption in another. Moreover, for more than a quarter century the Court never wavered in its commitment to the principle of the exemption doctrine, even if it applied it narrowly in fact.

In three decisions involving the denial of unemployment benefits, ${ }^{8}$ the Court required states to pay benefits to individuals whose inability to find work stemmed from their refusal to work in otherwise ordinary situations that conflicted with their religious beliefs. In each case, the Court made clear that, although any non-religious refusal to work could result in a denial of benefits, the Free Exercise Clause required the government to grant an exemption to those whose objections derived from religious beliefs. Thus, for example, a refusal to work on Saturdays due to childcare responsibilities could result in a denial of benefits, whereas a refusal to work on Saturdays due to religious beliefs could not. Similarly, in Wisconsin $v$ Yoder, ${ }^{9}$ the Court held that the Free Exercise Clause required the

\footnotetext{
${ }^{7}$ In one other case, an equally divided Court affirmed a lower court decision mandating a religious exemption from a state law requiring photographs on drivers licenses. Jensen $v$ Quaring, 472 US 478 (1985), affirming Quaring v Peterson, 728 F2d 1121 (8th Cir 1984).

${ }^{8}$ Sberbert $v$ Verner, 374 US 398 (1963); Thomas v Review Board, 450 US 707 (1981); Hobbie $v$ Unemployment Appeals Comm'n, 480 US 136 (1987).

${ }^{9} 406$ US 205 (1972).
} 
state to grant an exemption from its compulsory schooling laws to Amish parents who had religious objections to high school education. The Court noted that the state would not be required to grant such an exemption to a parent whose objection was "philosophical and personal," giving the example of an isolationism derived from Henry David Thoreau. ${ }^{10}$

Finally, in Corporation of the Presiding Bishop v Amos, ${ }^{11}$ the Court upheld a legislatively granted exemption, embracing reasoning parallel to that of Yoder. In Amos, the Court upheld a provision of Title VII that exempted religious organizations-including their secular activities-from the general prohibition against religious discrimination. The Court held that the exemption was designed "to alleviate significant governmental interference with" religious organizations, rather than to foster religion. Although the Court did not reach the question of whether the Free Exercise Clause would have required the exemption of its own force, the Yoder doctrine strongly suggests that it would have.

Thus the Court construed the Free Exercise Clause, from 1963 until its 1990 decision in Smith, to require, in at least some circumstances, religious exemptions from neutral laws of general applicability. During most of this period, however, the Court simultaneously interpreted the Establishment Clause to prohibit such exemptions.

The Court first fully enunciated the interpretation of the Establishment Clause that guided its decisions for more than two decades in Lemon $v$ Kurtzman. ${ }^{12}$ The Lemon doctrine, which was announced in 1971 but derived from several earlier decisions, ${ }^{13}$ prohibited any government support of religion (financial or otherwise) unless the government action had a secular purpose, had a primary effect that neither advanced nor inhibited religion, and avoided "excessive entanglement" with religion. Although inconsistently applied, especially in the area of aid to parochial schools, ${ }^{14}$ the Lemon doctrine

\footnotetext{
${ }^{10}$ Id at 216 .

${ }^{11} 483$ US 327 (1987).

${ }^{12} 403$ US 602 (1971).

${ }^{13}$ Board of Education v Allen, 392 US 236 (1968); Walz v Tax Comm'n, 397 US 664 (1970). See Lemon, 403 US at 612-13.

${ }^{14}$ For a list and description of the inconsistent cases, see, e.g., Michael A. Paulsen, Religion, Equality, and the Constitution: An Equal Protection Approacb to Establisbment Clause Adjudication, 61 Notre Dame L Rev 311, 315-17 (1986).
} 
was uniformly acknowledged to be a broad interpretation of the Establishment Clause which invalidated a great deal of government support of religion.

Most important for present purposes, the Lemon doctrine logically rendered the exemptions granted in the Yoder line of cases unconstitutional. ${ }^{15}$ This was so for several reasons. First, there is no secular purpose in discriminating between religious and nonreligious reasons for individual action. The only purpose is to accommodate religious beliefs, which is not a secular purpose. Second, at its very core, Lemon prohibited the government from preferring religion to non-religion. The exemptions established in the Court's Free Exercise decisions mandated precisely that preference by permitting those with religious objections, but not those with philosophical or other non-religious objections, to avoid the general law. Third, an effect-arguably the primary effect-of mandating such exemptions only for those with religious claims is to advance religion, at least in the sense of encouraging or enabling adherents to practice their religion while denying to others the right to live by their own philosophical principles. Thus people are encouraged to base their lives on religious as opposed to nonreligious principles. Fourth, to the extent that such exemptions require courts, legislatures, or administrators to determine which acts are religiously motivated, they result in siguificant entanglement of government with religion. Finally, at least in the unemployment benefits cases, nonadherent taxpayers were required to subsidize the religious beliefs of others. Indeed, it would seem that a religious exemption from a general law is no more secular-and thus no less a violation of the Establishment Clause-than an attempt to include parochial schools in a general program distributing educational maps to schoolchildren, which the Court struck down in Meek $v$ Pittenger, ${ }^{16}$ or a program allowing parochial and other private schools to use state school buses, which the Court invalidated in Wolman $v$ Walter. ${ }^{17}$

In fact, the Court itself occasionally recognized that Lemon prohibited special exemptions for religious beliefs, and even invali-

\footnotetext{
${ }^{\text {is }}$ See generally id at 339-40.

${ }^{16} 421$ US 349 (1975). See also Wolman $v$ Walter, 433 US 229 (1977).

${ }^{17} 433$ US 229 (1977).
} 
dated two such exemptions. In Estate of Thornton $v$ Caldor ${ }^{18}$ the Court applied Lemon to strike down a state law requiring employers to give employees their Sabbath day off, and in Texas Montbly, Inc $v$ Bullock ${ }^{19}$ the Court struck down a state's attempt to exempt religious publications from its general sales tax. Thus from at least 1971 until 1990, the Court's analysis of religious exemptions from general laws was inconsistent in both theory and practice.

Moreover, the Court's broad readings of both religion clauses effectively enabled it to pick and choose among religions, requiring or approving exemptions for some religions while invalidating (or not requiring) exemptions for others. It is noteworthy that, in general, the religions favored by the Court were marginal Christian religions that posed little or no threat to mainstream American Christianity. ${ }^{20}$ The Court required or approved exemptions for the Amish, Jehovah's Witnesses, Mormons, and Seventh-Day Adventists, all of which are long established Christian sects that have always remained relatively small in the United States. On the other hand, the Court consistently refused to require exemptions for Jews, ${ }^{21}$ non-Christian Native American religions, ${ }^{22}$ or fundamentalist Christian sects (which by their aggressive evangelical tactics and opposition to the secularization of mainstream Christianity threaten the established religious order). ${ }^{23}$ Thus, in addition to its internal inconsistency, the Court's approach to the religion clauses tended in application to accord protection primarily to those religious minorities who least need it, ${ }^{24}$ contrary to the usual conception of the role of the Court in protecting minorities from majoritarian abuse.

\footnotetext{
${ }^{18} 472$ US 703 (1985).

${ }^{19} 489$ US I (1988).
}

${ }^{20}$ See Frank Way \& Barbara J. Burt, Religious Marginality and the Free Exereise Clause, 77 Am Pol Sci Rev 652, 664-65 (1983). Lower court decisions may show a somewhat different pattern.

${ }^{21}$ See, e.g., McGowan v Maryland, 366 US 420 (1961); Braunfeld v Brown, 366 US 699 (1961); Goldman v Weinberger, 475 US 503 (1986).

${ }^{22}$ See Bowen v Roy, 476 US 693 (1986); Lyng v Nortbwest Indian Cemetery Prot. As'n, 485 US 439 (1988).

${ }^{23}$ See Bob Jones University v United States, 461 US 574 (1983); Tony @ Susan Alamo Foundation $v$ Secretary of Labor, 471 US 290 (1985); Jimmy Swaggart Ministries v Board of Equalization, 493 US 378 (1990).

${ }^{24}$ Cf. Mark Tushnet, The Constitution of Religion, 18 Conn L Rev 701, 718 \& n 90 (1986) (characterizing exemptions as occurring "in largely innocuous situations"). 


\section{False Reconciliations}

Neither Lemon nor Yoder is necessarily correct, although each reflects the core values of the clause it interprets. The Free Exercise Clause is designed to protect the exercise of religion from government interference. The Establishment Clause is designed to prevent the government from putting its imprimatur behind any one religion or religion in general. ${ }^{25} \mathrm{~A}$ broad reading of the free exercise principle of non-interference leads to Yoder; a broad reading of the establishment principle of no-imprimatur leads to Lemon (or some similar formula prohibiting the preferential treatment of religion). I will call these broad readings the "no interference" and "no discrimination" principles, respectively. ${ }^{26}$

There are four possible pairs of "pure" interpretations ${ }^{27}$ of the religion clauses: (1) we might interpret both clauses broadly, as the Court did under Yoder and Lemon; (2) we might interpret both clauses narrowly; (3) we might subordinate core Establishment Clause values to the Free Exercise Clause by adopting only the no-interference principle; and (4) we might subordinate the core Free Exercise Clause values to the Establishment Clause by adopting only the no-discrimination principle. In order, the consequences of these pairings for the issue of exemptions would be: (1) exemptions are both required and prohibited; (2) exemptions are permitted but not required; (3) exemptions are required; and (4) exemptions are prohibited.

In adopting the first alternative, the Court created a paradox that justices and scholars have been trying to resolve ever since. It is

\footnotetext{
${ }^{25}$ I believe that almost all of the scholars I discuss in this essay would agree with these formulations in the abstract.

${ }^{26}$ I chose "no discrimination" instead of "no preference" because the latter is too close to "non-preferentialism," which has become a term of art for the argument that the Establishment Clause prohibits only preferential aid to some religions but does not bar aid to religion in general over non-religion.

${ }^{27}$ Of course, there are also what might be called "diluted" interpretations, or intermediate approaches that blend two or more of the core interpretation pairs. Thus one might combine a "quasi-broad" interpretation of the Establishment Clause with a "narrow but not toothless" interpretation of the Free Exercise Clause. This type of intermediate approach, however, still raises the same question: why should we allow one clause to trump the other in specific situations? Making each clause more flexible does not reconcile the conflict, but only reduces it to a conflict that is resolved differently in each individual case. This merely adds further unpredictability, and does not eliminate the core conflict that requires us to subordinate one clause to the other.
} 
noteworthy that every proposed reconciliation of the tension between the two clauses has adopted one of the two subordinating solutions. Despite repeated claims that it is possible to give full value to the core principles of both clauses without creating a direct conflict between them, every proposed reconciliation has either recreated the paradox or devalued one of the two clauses. The various attempts at reconciliation fall into two broad categories: (1) attempts to distinguish among the various types of burdens that exemptions or failures to exempt place on nonbelievers and believers, often discussed in terms of "coercion"; and (2) attempts to determine whether exemptions or failures to exempt constitute religious discrimination, often discussed in terms of "neutrality." 28 will deal with each in turn.

\section{A. COERCION}

A common approach taken by some proponents of a strong Free Exercise Clause is to interpret the Establishment Clause as prohibiting only government coercion of religion. This approach claims to effect a reconciliation of the two clauses. In fact, however, it "solves" the problem by devaluing the Establishment Clause and rendering it essentially redundant and therefore unimportant.

Jesse Choper has suggested that the Establishment Clause should be read to forbid only government action that has both a solely religious purpose and the likely effect of "coercing, compromising, or influencing religious beliefs." ${ }^{29}$ It is therefore permissible to burden nonbelievers - even to impose "substantial costs" 30 - in order to relieve the burden on believers unless the non-believers' religious liberty is itself impaired, or tax funds are used to subsidize religious beliefs. ${ }^{31}$ Although he concludes that Sherbert was wrongly decided

\footnotetext{
${ }^{28}$ One scholar's attempt at reconciliation simply recreates the Court's own paradox by urging "a strong position on both [clauses]." Kathleen M. Sullivan, Religion and Liberal Democracy, 59 U Chi L Rev 195, 222 (1992).

${ }^{29}$ Jesse H. Choper, The Free Exercise Clause: A Structural Ovcrview and an Appraisal of Recent Developments, 27 Wm \& Mary L Rev 943, 948 (1986) ("Structural Overview"); accord, Jesse H. Choper, The Religion Clauses of the First Amendment: Reconciling the Confict, 41 U Pitt L Rev 673, 675 (1980) ("Religion Clauses").

${ }^{30}$ Choper, Religion Clauses at 694.

${ }^{31}$ Id at 677-80. He thus distinguishes, with little explanation, between "indirect social costs" (permissible) and tax subsidies (impermissible), noting only that the latter, unlike the former, "threaten the values undergirding the Establishment Clause." Id at 694.
} 
because other taxpayers were required to subsidize Ms. Sherbert's religious refusal to work Saturdays, ${ }^{32}$ he approves of most other types of exemptions as mere accommodations of religion that do not burden the religious liberty of nonbelievers. ${ }^{33}$

Michael McConnell appears similarly attracted to the notion of requiring coercion for a finding of an Establishment Clause violation. ${ }^{34}$ In his most recent discussion of the issue, however, he suggests that even the presence of coercion may not make out a violation of the Establishment Clause because religious exemptions will always "involve government coercion of some sort." 35 Thus, in his view, exemptions may pass constitutional muster despite the presence of coercion.

A majority of Justices have also endorsed a coercion test, although they have not yet agreed on the details of its application. In 1989 in County of Allegheny $v A C L U,{ }^{36}$ Justice Kennedy, joined by Chief Justice Rehnquist and Justices White and Scalia, would have made coercion the "sole touchstone" of Establishment Clause violations, "for it would be difficult indeed to establish a religion without some measure of more of less subtle coercion." 37 All four of these Justices agreed that placing a creche on public property did not constitute even subtle coercion and was therefore constitutional. This past term, in Lee $v$ Weisman, ${ }^{38}$ Justice Thomas also endorsed a coercion test, and only a technical dispute about the definition of coercion prevented a majority of the Court from officially adopting this standard.

Despite this lack of an explicit majority, Lee $v$ Weisman clearly signals the death of Lemon and the adoption of a coercion test. In Weisman, Justice Kennedy wrote for a five-Justice majority inval-

\footnotetext{
32 Id at 690-92; Choper, Structural Overvierw at 949.

${ }^{33}$ Choper, Religion Clauses at 685.

${ }^{34}$ In Michael W. McConnell, Coercion: Tbe Lost Element of Establisbment, 27 Wm \& Mary L Rev 933 (1986), he argued that only coercive governmental action violates the Establishment Clause. More recently, however, he has suggested that a coercion test "could tend toward acquiescence in more subtle forms of governmental power." McConnell, Religious Freedom at a Crossroads, U Chi L Rev 115, 159 (1992) ("Crossroads"). I assume that he would approve
} of an Establishment Clause test that incorporated coercion broadly defined.

${ }^{35}$ McConnell, Crossroads at 165.

${ }^{36} 492$ US 573 (1989).

${ }^{37}$ Id at 659, 660-61 (opinion of Kennedy).

${ }^{38} 112$ S Ct 2649 (1992). 
idating state-sponsored prayer at a public school graduation. Justice Scalia dissented, along with Chief Justice Rehnquist and Justices White and Thomas. The dissenters thought coercion was a necessary element of an Establishment Clause violation, and found none on the facts of the case.

The dispute between the majority and the dissent centered on whether the psychological coercion inherent in the graduation context was sufficient to violate the Establishment Clause. Justice Kennedy's majority opinion relied entirely on the coercive aspect of the setting; he cobbled together a majority by studiously ignoring Lemon" and by stating that "at a minimum, the Constitution guarantees that government may not coerce anyone to support or participate in religion or its exercise." 40

Although joining Justice Kennedy's opinion, the other four justices in the majority recognized that Kennedy, building upon his opinion in Allegheny County, was prepared to substitute a coercion test for Lemon. They therefore found it necessary to add two separate concurring opinions emphasizing that the Establishment Clause prohibited more than government coercion. In a concurring opinion joined by Justices Stevens and O'Connor, Justice Blackmun explained that he joined the Court's opinion only "because [he found] nothing in it inconsistent with the essential precepts of the Establishment Clause," adding that "[a]lthough . . . proof of government coercion is not necessary to prove an Establishment Clause violation, it is sufficient." ${ }^{41}$ Justice Souter, also joined by Justices Stevens and O'Connor, wrote separately to address the question "whether state coercion of religious conformity, over and above state endorsement of religious exercise or belief, is a necessary element of an Establishment Clause violation." ${ }^{42} \mathrm{He}$ concluded

\footnotetext{
${ }^{39} \mathrm{He}$ stated explicitly that the case did "not require [the Court] to revisit the difficult questions dividing [it] in recent cases," and that the Court thus would "not accept the invitation of petitioners and amicus the United States to reconsider our decision in Lemonv. Kurtzman." Id at 2655.

${ }^{+0} \mathrm{Id}$. He continued that government may not "otherwise act in a way which "establishes a [state] religion or religious faith, or tends to do so." "Id. This formulation adds nothing to the coercion test. It is a mere restatement of the Establishment Clause itself, and in Allegheny County Kennedy conflated it with the coercion test by stating that "it would be difficult indeed to establish a religion without some measure of more or less subtle coercion." 492 US at 659.

\$l $112 \mathrm{~S} \mathrm{Ct}$ at 2664 (Blackmun, J, concurring).

${ }^{42}$ Id at 2667 (Souter, J, concurring).
} 
it was not. Thus, although joining Justice Kennedy's opinion, each of these Justices found it necessary to counter the clear implication that government coercion is essential to a violation of the Establishment Clause. Indeed, even the dissenters read Justice Kennedy's opinion as abandoning Lemon in favor of a coercion standard. ${ }^{43}$

The Court's new coercion test is similar to the approaches recommended by Choper and McConnell. In the exemption context, the Court, after Smith, apparently will use the coercion standard to test the constitutionality only of legislatively granted exemptions, whereas the commentators would also use it to determine whether exemptions that might be required by the Free Exercise Clause are consistent with the Establishment Clause. The basic principles urged by the commentators and adopted by the Court are similar, however, and suffer from identical flaws.

The first flaw in the coercion test is the one identified-and put aside-by McConnell. As long as nonbelievers are required either to obey the offending law or, worse, to take on an additional burden to enable believers to disobey (as in Amos or cases where nonbeliever employees must work undesirable shifts to cover for Sabbath observers), there will be some form of government coercion.

Choper attempts to avoid this problem by suggesting that the Establishment Clause is violated only if religious beliefs are coerced. He defines religious beliefs to exclude all beliefs about religion which are not themselves religiously derived (atheism, for example). ${ }^{44}$ Michael Paulsen-who combines the no-discrimination and coercion arguments in favor of exemptions-makes a similar argument. He maintains that there is a difference between "religion" and "religious belief or exercise," and that "[a] nonbeliever's objection [thus] arises only when [the costs of the exemption] actually abridge or injuriously discriminate against his freedom of nonexercise. ${ }^{\prime 45}$ On this view, religious accommodation that burdens nonbe-

\footnotetext{
${ }^{43}$ Id at 2685 (Scalia, J, dissenting).

* Although that is implicit in his general discussion of the differences between ordinary burdens and burdens on religious liberty, he makes it explicit when he states that Epperson $v$ Arkansas, 393 US 97 (1968), invalidating a law prohibiting the teaching of evolution, was wrongly decided because the law did not coerce anyone's religious beliefs. Since the law permitted the teaching of creationism, the beliefs that were compromised were scientific, non-religious beliefs rejecting the religious doctrine.

${ }^{45}$ Michael A. Paulsen, Religion, Equality, and the Constitution: An Equal Protection Approacb to Establishment Clause Adjudication, 61 Notre Dame L Rev 311, 336-37 (1986) ("Religion and Equality").
} 
lievers, but does not curtail their freedom not to believe, does not violate the Establishment Clause.

This line of argument raises three parallel problems. First, under Choper's view, the anti-evolution statute invalidated in Epperson $v$ Arkansas $^{46}$ is constitutional because it does not impair religious liberty. ${ }^{47}$ This view fails to recognize that it may impair religious liberty for the government to suppress non-religiously derived beliefs that religious doctrine is erroneous-in other words, the freedom to believe carries with it the freedom not to believe. ${ }^{48}$ Second, both Choper's and Paulsen's definitions of coercion are too narrow insofar as they fail to recognize that any government preference for religious over non-religious beliefs will necessarily influence religious beliefs, and thus subtly burden non-religious belief or exercise. ${ }^{49}$ Finally, by arguing that the government may burden some people in order to support other people's religious beliefs, as long as it does not burden the first group's religious beliefs, the proponents of this position single out religious beliefs from other beliefs for special treatment. Unless they can demonstrate that religious beliefs are different from other beliefs, such a preference is antithetical to the core values of the Establishment Clause. ${ }^{50}$ Thus, this "reconciliation" of the tension merely subordinates the Establishment Clause to the Free Exercise Clause.

The second problem with requiring coercion as an element of an Establishment Clause violation is that such an approach makes the Establishment Clause redundant. Any government action that coerces religious belief violates the Free Exercise Clause. Although

\footnotetext{
46393 US 97 (1968).

${ }^{47}$ Choper, Religion Clatses, 41 U Pitt L Rev at 687-88 (cited in note 29).

${ }^{48}$ See Kathleen M. Sullivan, Religion and Liberal Democracy, 59 U Chi L Rev 195, 205 (1992). Paulsen, to his credit, does not fall into this trap.

${ }^{49}$ Of course, any preference for secular over religious beliefs will have the opposite effect, and might therefore undermine free exercise values. It is thus hard to see how any government action in which there are religiously based differences can fail to coerce, or at least influence, someone's religious beliefs. This is analogous to the problem with defining "neutrality" in this context. See pp. 135-46. Paulsen explicitly denies that coercion is implicit in government endorsement of religion. Although he would prohibit government coercion of religion, he notes that "[n]either a creche nor a legislative chaplaincy abridges the religious liberty of the nonadherent through either compulsion or inducement, and these symbolic uses of religion do not tbemselves communicate a message of disapproval of such nonadherence." Paulsen, Religion \& Equality at 353.

${ }^{50}$ The possibility of differentiating between religious and non-religious beliefs is discussed more fully in the next section.
} 
virtually all commentators (and the Court) agree that direct coercion of religious beliefs violates the Free Exercise Clause, the redundancy problem is especially acute for those who take an accommodationist approach, since they include even indirect coercion among Free Exercise violations. As Douglas Laycock has observed, "[c]oercion to observe someone else's religion is as much a free exercise violation as is coercion to abandon my own." ${ }^{51}$ If all governmental coercion concerning religious beliefs violates the Free Exercise Clause, a coercion-based Establishment Clause does not prohibit anything that is not independently prohibited by the Free Exercise Clause.

The third and most obvious problem with the coercion requirement is that it conflicts with the plainest possible meaning of the Establishment Clause, for it would permit Congress to establish a church, as long as no one was required to join. ${ }^{52}$

Even if the Establishment Clause prohibits more than government coercion, however, there is significant dispute about the extent to which it prohibits government favoritism toward religion. This dispute takes the form of debate about discrimination and neutrality, to which I now turn.

\section{B. NEUTRALITY}

The central problem with the neutrality solution to the issue of religious exemptions is that, in this context, there is no such thing as neutrality. If an exemption is granted, then the government (whether the legislature or the Court) facially discriminates in favor of religion, as when it exempts the Amish but not the followers of Thoreau from compulsory schooling laws. If, on the other hand, no exemption is granted, then the government discriminates in effect against those with religious objections to the law, as when a compulsory schooling law fails to exempt the Amish. Thus, as one

\footnotetext{
${ }^{51}$ Douglas Laycock, "NonPreferential" Aid to Religion: A False Claim About Original Intent, 27 Wm \& Mary L Rev 875, 922 (1986) ("A False Claim"). See also Douglas Laycock, "Noncoercive" Support for Religion: Anotber False Claim About tbe Establisbment Clause, 26 Valp L Rev 37 (1991) ("Another False Claim"); Kathleen M. Sullivan, Religion and Liberal Democracy, 59 U Chi L Rev 195 (1992); Mark V. Tushnet, Reflections on tbe Role of Purpose in tbe Jurisprudence of the Religion Clatses, 27 Wm \& Mary L Rev 997 (1986). Justice Souter's concurring opinion in Weisman makes the same point. $112 \mathrm{~S} \mathrm{Ct}$ at 2672-73.
}

${ }^{32}$ See Laycock, A False Claim at 39. 
scholar has noted, "the very concept of neutrality is inherently indeterminate. $" 53$

Most proponents of accommodation recognize this difficulty, and counter with a call for substantive rather than formal neutrality. ${ }^{54}$ But unlike formal neutrality, which requires only that the government not single out religion for special treatment, the meaning of substantive neutrality is unclear in this context. The meaning assigned by those who favor accommodation, however, leads to an exceedingly narrow interpretation of the Establishment Clause.

The major modern proponent of accommodation and a broad Free Exercise Clause, at the expense of the Establishment Clause, is Michael McConnell. Although his theory of the religion clauses has developed over time-leading to several possible interpretations of his position-the core of his interpretation of the clauses is that together they protect religious liberty 55 against "governmentinduced homogeneity" or "uniformity." special exemptions for religion foster this goal because they enable citizens to follow their individual consciences. This echoes the Court's explanation that exemptions are permissible when (and only when) they "alleviate significant governmental interference with" religious beliefs and practices. ${ }^{57}$

Both McConnell and the Court explicitly deny that granting exemptions discriminates against the non-religious. McConnell suggests that secular objectors, who, under Yoder, are not granted an exemption, "suffer little or no consequence at all" in having to obey general laws because nonbelief "entails no obligations and no observances." ${ }^{58}$ Religious beliefs are different, he argues, because

${ }^{53}$ Steven D. Smith, Symbols, Perceptions, and Doctrinal Illusions: Establisbment Neutrality and the "No Endorsement" Test, 86 Mich L Rev 266, 315 (1987).

${ }^{54}$ See, e.g., Douglas Laycock, Formal, Substantive, and Disaggregated Neutrality Toward Religion, 39 DePaul L Rev 993 (1990) ("Neutrality"); Michael W. McConnell, Accommodation of Religion: An Update and a Response to the Critics, 60 Geo Wash L Rev 685, 729 (1992) ("Update"); Michael W. McConnell \& Richard A. Posner, An Economic Approacb to Isstes of Religious Freedom, 56 U Chi L Rev 1, 10-12, 33 (1989).

${ }^{55}$ Michael W. McConnell, Accommodation of Religion, 1985 Supreme Court Review 1 ("Accommodation").

${ }^{36}$ McConnell, Crossroads at 168, 169.

57 Corporation of the Presiding Bisbop v Amos, 483 US 327, 335 (1987). See also Texas Montbly, Inc. $v$ Bullock, 489 US 1, 18 \& n 8 (1988).

${ }^{58}$ McConnell, Accommodation, at 9, 10-11; see also Michael W. McConnell, Neutrality Under the Religion Clatses, $81 \mathrm{Nw}$ U L Rev 146, 152 (1986) (nonbelievers suffer only "slight inconvenience") ("Neutrality"). He does admit that non-religious moral convictions are entitled to "special respect," but not to the extent of granting exemptions. Accommodation at $11-12$. 
they are "matter[s] over which we have no control-the demands of a transcendent authority." 59 Thus there is no discrimination in granting religious exemptions because only the religious are harmed in this way by the law. The Court has similarly denied that exemptions are discriminatory, suggesting in Sherbert that the required exemption "reflects nothing more than the governmental obligation of neutrality in the face of religious differences." ${ }^{60}$ Both the Court and McConnell therefore characterize the granting of exemptions as a form of neutrality that implements the values of the Free Exercise Clause without diminishing the Establishment Clause's prohibition of discrimination in favor of religion over nonreligion. ${ }^{61}$

There are two problems with this explication of the religion clauses. First, McConnell's initial premise seems to be that nonbelievers do not suffer the same sort of harm as believers from having to obey a law. But as William Marshall has pointed out, the dilemma of conflicting duties arises "anytime one's beliefs conflict with those of the state, whether those beliefs are religious or not." Secularly derived beliefs may be as deeply and sincerely held as religious beliefs. The parent who believes that it is her moral obligation as a parent to spend time with her children on the weekends because she must be away from them during the week suffers the same consequences from having to work on Saturdays as does the Seventh-Day Adventist who believes that her God commands her to refrain from working on Saturday. In both cases there is a deeply felt moral obligation imposed from without (from God or from principles of moral rightness) and not affected by the individual's

\footnotetext{
${ }^{59}$ McConnell, Crossroads at 172 . It is interesting to compare this statement, which concludes with his comment that religious beliefs, unlike secular beliefs, are not "the product of free and voluntary choice," with his derogatory comment that the Justices tend to view religion as the result, not of "thoughtful consideration and experience" but of "conformity and indoctrination." Id at 122 . If religious beliefs are entitled to special treatment specifically hecause they are commands that must be obeyed rather than voluntary choices, then perhaps the Justices are correct in their assessment of religion as implicating conformity and indoctrination.

${ }^{60}$ Sherbert $v$ Verner, 374 US 398, 409 (1963). See also Hobbie v Unemployment Appeals Comm't, 480 US 136, 145 n 11 (1987) (exemption "does not single out a particular class of ... persons for favorable treatment").

${ }^{61}$ McConnell's latest scholarship explicitly notes that discrimination in favor of religion over non-religion is prohibited by the Establishment Clause, see McConnell, Crossroads at 175.

${ }^{62}$ William P. Marshall, Tbe Case Against Constitutionaliy Compelied Free Exercise Exemptions, 40 Case W Res L Rev 357, 383 (1989-90) ("Case Against Exemptions").
} 
own likes or dislikes. In both cases, the individual is placed in the difficult position of having to choose between sacred-to herobligations and financial necessity.

I use the word "sacred" deliberately: it highlights the second problem with the McConnell position. McConnell's characterization of secular beliefs as not productive of the conflicts that result from religious beliefs is descriptively erroneous. However, he may instead be basing his argument-and the right to exemptions-on a normative notion that only religious beliefs should be treated as sacred by the government. To the extent that he is making that claim, however, he is urging overt government discrimination in favor of religious beliefs by "den[ying] religious and secular beliefs equal constitutional dignity." ${ }^{63}$ This not only undermines the heart of the Establishment Clause by preferring religion to non-religion, it also runs afoul of the core principles of the Free Speech Clause, which suggest that "every idea is of equal dignity and status in the marketplace of ideas."

McConnell's understanding of the core purposes of the religion clauses supports this normative reading of his argument, but also further demonstrates that under his version of neutrality the Free Exercise Clause will always trump the Establishment Clause. His interpretation makes the two clauses redundant: the Free Exercise Clause prohibits "inhibiting religious practice" and the Establishment Clause prohibits "forcing or inducing a contrary religious practice. ${ }^{.65}$ But anything that forces me to observe a contrary religious practice necessarily inhibits my own religious practiceswhether by forcing me to do what violates my own religious precepts, such as praying to a God I do not believe in, or by reducing

\footnotetext{
${ }^{63}$ Id at 393. See generally id at 388-92.

64 William P. Marshall, In Defense of Smith and Free Exercise Revisionism, 58 U Chi L Rev 308, 320 (1991). See also Marshall, Case Against Exemptions, at 394.

${ }^{65} \mathrm{McC}$ Connell, Crossroads at 169 . To the extent that McConnell here appears to be endorsing coercion as a necessary element of an Establishment Clause violation, see my discussion at pp. 133-35. A similar formulation of the purposes of the religion clauses has been proposed by Mary Ann Glendon and Raul F. Yanes. They suggest that the "overarcbing purpose [of the clauses is] to protect freedom of religion." Again, however, their definitions make the Establishment Clause redundant: according to them, the clauses together "bar Congress from abridging religious freedom in one specific way [the Establishment Clause], and in general [the Free Exercise Clause]." Mary Ann Glendon \& Raul F. Yanes, Structural Free Exercise, 90 Mich L Rev 477, 541 (1991). Moreover, unlike McConnell, tbey would not require neutrality between religion and non-religion, id at 539, and thus would further minimize the Establishment Clause.
} 
the time and money I have available to support my own religion. Similarly, McConnell's understanding eliminates any independent meaning for the Establishment Clause: "Taken together, the Religion Clauses can be read most plausibly as warding off two equal and opposite threats to religious freedom-government action that promotes the majority's favored brand of religion and government action that impedes religious practices not favored by the majority." McConnell obviously believes that these are two distinct threats, but it is not clear how any government action could promote one religion without simultaneously impeding others. This is especially problematic for those who, like McConnell, find that even indirect and unintentional inhibitions on religious practices violate the Free Exercise Clause. Thus every Establishment Clause violation is also a Free Exercise violation (although not vice versa), and the definitions render the Establishment Clause a nullity.

The crux of the problem with McConnell's interpretation of the religion clauses is that it fails to recognize the shades of meaning that might be comprehended by such terms as "inhibiting," "forcing," "promot[ing]," and "imped[ing]." Like "neutrality," these terms can refer either to government action that intentionally or facially favors or disfavors religious over non-religious practices, or it can refer to the actual or perceived effect of the government action. An atheist might reasonably believe that the government is forcing or promoting deism (or religion in general) when it accommodates those whose objection to obeying the law stems from religion but not those whose objection stems from secular beliefs, just as a believer is convinced that the government is inhibiting religion if it fails to grant an exemption. But McConnell's scheme leaves room only for the believer's objection and not for the atheist's; he does not consider accommodation as promoting religion.

McConnell's failure to recognize the atheist's claim as valid stems from his disparate treatment of religious and secular beliefs. McConnell accepts without question perceptions derived from religious beliefs, but rejects perceptions derived from contrary beliefs. For example, the eternal consequences of obeying a law in conflict with religious beliefs are all in the believer's mind (there are no tangible consequences that can be perceived by an objective observer). McConnell nevertheless counts as a cost the non-tangible

${ }^{\circ}$ McConnell, Update at 690. 
harm that derives from ignoring those idiosyncratic and nonverifiable beliefs. On the other hand, McConnell "rules out of bounds costs consisting solely of aversions toward religion or particular faiths." ${ }^{~} 67$ In other words, if I believe that I will be eternally damned if I work on Saturday, for the government to force me to do so imposes a cost on me. If, by contrast, I believe that religion condemns humanity to a stunted and uncreative future, for the government to foster religion by preferring your religious to my secular motivations in allocating benefits imposes no cost on me. In either case, however, there is neither a way to verify the beliefthat I will be damned or that humanity will be stunted-nor any objective way to reckon the cost to me if the government acts in a way inconsistent with beliefs. ${ }^{68}$

The differentiation between religious and nonreligious beliefs thus plays a key role in McConnell's theories of accommodation. That distinction underlies the normative decision to treat only religious beliefs as worthy of special protection and also defines the sorts of non-tangible effects that will count for purposes of measuring discriminatory effects.

In order to explain and justify such differential treatment of religious and non-religious beliefs, McConnell must demonstrate that they are different in a relevant, if not compelling, way. Apart from the unsupported assertion that religious beliefs, unlike secular beliefs, are commands, and the oft-repeated observation that the Constitution singles out religion for special treatment, ${ }^{69}$ no one has distinguished religious from non-religious beliefs in such a way as to justify the discrimination inherent in preferring religious beliefs. That the Constitution singles out religion is not itself persuasive, for it singles out religion for both preferential and disadvantageous

\footnotetext{
${ }^{67}$ McConnell \& Posner, 56 U Chi L Rev at 35 (cited in note 54).

${ }^{68}$ One might try to label the costs to the religious believer as "Hohfeldian" and those to the nonbeliever as "non-Hohfeldian," but that characterization depends on a prior assumption that the nonbeliever's interest in humanity's future is different from the believer's interest in his own afterlife. Needless to say, that very distinction also depends on the beliefs of the two individuals, and may vary (some believers may be more concerned about humanity than about themselves, for example). Thus reckoning the cost, and differentiating between costs, ultimately depends on how one treats the individual's own beliefs.

${ }^{69}$ See, e.g., MicConnell, Update at 717; Douglas Laycock, The Remnants of Free Exercise, 1990 Supreme Court Review 1, 16; Paulsen, 61 Notre Dame L Rev at 337 (cited in note 45).
} 
treatment: the Establishment Clause and Free Exercise Clauses together bar the government not only from interfering with individual religious beliefs but also from favoring them. ${ }^{70}$ This is unlike the Free Speech Clause, for example, which does not bar the government from speaking itself. ${ }^{71}$ The most intriguing attempt to explain how religious beliefs are unique is John Garvey's. He suggests that "religion is a lot like insanity" in that true believers may be unable to perceive reality the way others do and may thus be unable to conform their conduct to the law in light of their perception that God commands them to do otherwise. ${ }^{72}$ This hardly serves as a justification for requiring the government to cater to what would, in the insane, be called delusions. Thus, no attempt to distinguish religious from non-religious beliefs has successfully justified granting exemptions to religious objectors but not to secular objectors.

Thus McConnell-and the Court in its rare attempts to explain away the tension between its establishment and free exercise jurisprudence-achieves a resolution between the two clauses only by making the Establishment Clause virtually meaningless, at least in the context of exemptions that privilege religious objectors over secular objectors. In McConnell's view, the Establishment Clause prohibits the government from giving money to "religion qua reli-

\footnotetext{
${ }^{70}$ The argument that the Founders must have thought religion was different-otherwise they would not have adopted the religion clauses-does not get us very far. First, it is possible to read the Free Exercise Clause as a particularized version of the Free Speech Clause, guaranteeing only that the government could not suppress religious belief or expression any more than it could suppress political expression. For an elaboration of this argument, see Steven G. Gey, Why Is Religion Special? Reconsidering the Accommodation of Religion Under the Religion Clauses of the Fint Amendment, 52 U Pitt L Rev 75, 148 (1990). The Establishment Clause might then be read as a way of ensuring that religion would not be treated differently. Second, even if the founding generation believed that religion was different and therefore entitled to special consideration (and the best reading of the history, as with most such disputes, is probably that some did and some didn't), their intent might be incoherent in a modern regulated state. Finally, basing modern interpretations of the Constitution on the specific intent of the framers is controversial, to say the least.

"Justice Kennedy's majority opinion in Weisman recognized this difference in the context of government speech about religion. $112 \mathrm{~S} \mathrm{Ct}$ at 2657-58. See also Sullivan, $59 \mathrm{U} \mathrm{Chi} \mathrm{L}$ Rev at 206 (cited in note 51) ("there is no political establishment clause").

72 John H. Garvey, Free Exercise and the Values of Religious Liberty, 18 Conn L Rev 779, 798-800 (1986). If that is in fact an accurate account of the difference between religious and non-religious beliefs, one should also note that the insane who commit crimes may not be punished but are nevertheless locked up until they give up their delusions. They are certainly not given carte blanche to disobey whatever law their delusions made them unable to obey.
} 
gion," 73 but does not prohibit the government from subsidizing Ms. Sherbert's religious beliefs or granting a sales tax exemption only to religious publications. ${ }^{74} \mathrm{McC}$ Connell's Establishment Clause would prohibit little beyond direct discrimination among faiths or legislative declarations that everyone must tithe or attend churchrather remote legislative possibilities. ${ }^{75} \mathrm{McConnell}$ comments that the difference between substantive and formal neutrality "is the difference between a Free Exercise Clause that is a major restraining device on government action ... and a Free Exercise Clause that will rarely have practical application."76 That is true. But McConnell's position reduces the Establishment Clause to just such a practical nullity.

Other scholars similarly reconcile the two clauses-and label their reconciliation "neutrality"-by elevating the core values of the Free Exercise Clause over those of the Establishment Clause. Douglas Laycock advocates "substantive neutrality": the government should "minimize the extent to which it either encourages or discourages religious belief or disbelief, practice or nonpractice, observance or nonobservance." 77 According to Laycock, although no government act in this context can be wholly neutral, we can distinguish between the minor encouragement of religion that occurs when an exemption is granted and the severe discouragement of religion that occurs when an exemption is denied. He offers as illustration the question whether to grant an exemption from Prohibition for the religious use of wine. ${ }^{78}$

What Laycock, like McConnell, fails to appreciate is that whenever government attempts to remedy a de facto discrimination against religion by granting an exemption to religious objectors it

\footnotetext{
${ }^{73}$ McConnell, Crossroads at 185.

${ }^{74} \mathrm{He}$ suggests that his approach would mandate a judicial return to the Sberbert-Yoder regime, "albeit with more vigorous and consistent enforcement," McConnell, Crossroads at 170 , and nowhere suggests that any legislatively granted exemption is unconstitutional.

${ }^{75}$ McConnell does suggest that it might violate the Establishment Clause if the government influenced or subtly coerced a captive or vulnerable audience into conformity with government-preferred religious beliefs. See Crossroads at 158. Such coercion, however, would probably also violate the Free Exercise Clause since the coercion would operate to impede the audience's adherence to its own religious beliefs as well. The reduudancy created by using a coercion test is discussed at pages 134-35.

${ }^{76} \mathrm{McC}$ Connell, Update at 689.

${ }^{77}$ Laycock, Remnants, 1990 Supreme Court Review at 16.

${ }^{78}$ Laycock, Neutrality, 39 DePaul L Rev at 1000-1003.
} 
creates an equally noxious de jure discrimination against nonbelievers. For the government to grant only religious exemptions sends a message that religious belief is valued more than nonbelief (or non-religious belief) ${ }^{79}$ and encourages religious belief. The fact that, as Laycock points out, it does not directly encourage religious belief $^{80}$ (most parents are not about to become Amish in order to avoid compulsory schooling laws) does not change the fact that the message is there. As Laycock himself observes, 83 percent of the American public claims to feel "close to God," 81 and any government preference for religiously derived values over secularly derived values can only compound the pressure nonbelievers experience when they are reminded that America is a religious nation. How one evaluates the magnitude of the effect-whether it is minor or severe-depends on how one values the intangible, nonfalsifiable beliefs of both the religious and the non-religious. The harm done to believers who are prevented from practicing their religion is no different in kind or degree from the harm done to nonbelievers (in particular to atheists and others who subscribe to secular rather than religious worldviews) who are branded as unwelcome secondclass citizens and implicitly informed that they will be welcome if only they will embrace the right beliefs. One's own perspective determines both which harm is considered greater and which principle-no-discrimination or no-interference-has priority. An unsympathetic atheist may scoff just as much at the believer's claim of religious compulsion as the believer may scoff at the atheist's sense of exclusion. Each may say, with equal justification, that the other suffers no real or tangible injury. Only by distinguishing religious beliefs from other beliefs (including non-religiously derived beliefs about religion) can Laycock distinguish the two harms.

Ira Lupu also champions a form of "neutrality," which he labels the pursuit of "equal religious liberty." Under his scheme, how-

\footnotetext{
${ }^{79}$ Mark Tushnet, who has wavered between advocating formal neutrality and advocating substantive neutrality, has made the same observation. Mark Tushnet, Tbe Emerging Principle of Accommodation of Religion (Dubitante), 76 Geo L J 1691, 1703 (1988) ("Dubitante").

80 Laycock, Remnants at 17.

${ }^{81}$ Douglas Laycock, Vicious Stereotypes in Polite Society, 8 Const Comm 395, 397 (1991).

${ }^{82}$ Ira C. Lupu, Reconstructing tbe Establisbment Clause: Tbe Case Against Discretionary Accommodation of Religion, $140 \mathrm{U} \mathrm{Pa}$ L Rev 555, 567-68 (1991) ("Reconstructing the Establishment Clause"); Ira C. Lupu, Keeping tbe Faitb: Religion, Equality and Speecb in tbe U.S. Constitution, 18 Conn L Rev 739 (1986) ("Keeping the Faith").
} 
ever, the government is permitted to aid religion along with nonreligion in some cases, and is required to aid religion alone in others. ${ }^{83}$ Lupu, like McConnell and Laycock, recognizes the burden formal neutrality (no facial discrimination for or against religion) can place on religious believers, and rectifies it in the same way: by allowing facial discrimination in favor of religion where it is necessary to relieve the discriminatory effect on believers. Again, however, he fails to appreciate that this does not resolve the conflict, but simply shifts the burden of discriminatory effects from believers to nonbelievers. Moreover, to the extent that he interprets the Free Exercise Clause to protect religious liberty and the Establishment Clause to protect equal religious liberty, ${ }^{84}$ the Establishment Clause appears to add nothing to what is already protected by the Equal Protection Clause of the Fourteenth Amendment. ${ }^{85}$

Mark Tushnet once suggested ${ }^{86}$ a "reconciliation" that, while not explicitly couched in terms of "neutrality," suffers from the same flaws. He formulated a seemingly simple resolution of the tension between the two clauses, at least in the area of religious exemptions: "[o]ne could . . . interpret the establishment clause to prohibit all statutes that have a religious purpose, except for statutes with the purpose of accommodating religion in ways required by the free exercise clause." 87 Thus the breadth of the Free Exercise Clause is matched by a narrowing of the Establishment Clause. But there is no way to explain why this formulation is better than its opposite: interpret the Free Exercise Clause to require only those religions

${ }^{83}$ Lupu, Reconstructing the Establisbment Clause at 588-89, 594-95. See also Paulsen, Religion of Equality at 314, 354-56 (cited in note 45). Paulsen, like Lupu, suggests that the religion clauses together protect "equality of religious freedom," mandating "neutrality." ld at 314, 332.

${ }^{84}$ Lupu, Keeping the Faith at 742.

85 The fact that the Establishment Clause predates the Equal Protection Clause by more than half a century - and predates the modern interpretation of the Equal Protection Clause by which religious minorities are protected from discrimination by almost two centuriesmight matter only to hardcore originalists. What most courts and scholars are struggling with today is not the original meaning of the Constitution, but the modern meaning. Moreover, as suggested at pp. 147-48, the founders' original intent may be incoherent in the context of today's activist state.

${ }^{86}$ He has apparently since abandoned that position and moved into the "formal neutrality" camp. See Tushnet, Dubitante (cited in note 76); Mark Tushnet, "Of Churcb and State and the Supreme Court": Kurland Revisited, 1989 Supreme Court Review 373.

${ }^{87}$ Mark V. Tushnet, Reflections on tbe Role of Purpose in tbe Jurisprudence of tbe Religion Clauses, 27 Wm \& Mary L Rev 997, 1007 (1986). See also Geoffrey R. Stone, Constitutionally Compelled Exemptions and the Free Exercise Clause, 27 Wm \& Mary L Rev 985, 994 (1986). 
exemptions not prohibited by the Establishment Clause, and then interpret the Establishment Clause broadly. Similarly, Michael Paulsen suggests that "protecting the constitutional right to the free exercise of religion" should constitute a compelling governmental interest sufficient to withstand Establishment Clause scrutiny. ${ }^{88}$ This formulation can also be reversed: protecting the values of the Establishment Clause should constitute a compelling government interest sufficient to justify the impact of neutral laws on religious exercise. Whichever clause serves as the compelling interest trumps the other. Which formulation one prefers depends solely on whether one places a higher priority on the values of the Establishment Clause or on those of the Free Exercise Clause.

If some alleged reconciliations of the religion clauses achieve their goal by subordinating the Establishment Clause, others make the opposite mistake. Those who oppose exemptions for believers often fail to see that neutral laws, rigidly applied, constitute a form of discrimination against believers, contrary to the values of the Free Exercise Clause. These scholars' "reconciliations" simply interpret the Free Exercise Clause narrowly, thus subordinating its core values to those of the Establishment Clause.

Philip Kurland is perhaps the strongest proponent of the rule against exemptions. Calling for neutrality, he suggests not only that courts should not grant religious exemptions (i.e., Yoder was wrongly decided), but also that legislatures should be prohibited from granting such exemptions (i.e., Amos was wrongly decided). ${ }^{89}$ Although his scheme achieves formal neutrality, it effectively privileges Establishment Clause values over Free Exercise Clause values by upholding laws that have a severe discriminatory effect on religious believers. Just as one interpretation of the Establishment Clause prohibits the government from discriminating-facially or in effect-against nonbelievers, one interpretation of the Free Exercise Clause protects believers from the discriminatory effect of neutral laws. Kurland does not satisfactorily take into account this possible reading of the Free Exercise Clause. Thus just as McConnell and others undervalue the discrimination inflicted by exemp-

\footnotetext{
${ }^{88}$ Paulsen, Religion \& Equality at 341-42 (cited in note 45 ).

${ }^{89}$ See Philip B. Kurland, The Irrelevance of the Constitution: The Religion Clauses of the First Amendment and the Supreme Court, 24 Vill L Rev 3 (1978-79); Philip B. Kurland, Religion and the Law (1962).
} 
tions, Kurland undervalues the discrimination-eloquently described by McConnell and others $\mathrm{s}^{90}$-inflicted by neutral laws.

William Marshall also opposes exemptions for religious objectors, but only those that have been imposed by judicial interpretation of the Free Exercise Clause. He apparently would uphold legislatively granted exemptions. ${ }^{91}$ Because this is the approach that seems to command a majority of the current Court, I will engage in a fuller discussion of this position later. ${ }^{92}$ For now, it is sufficient to note that although Marshall recognizes that a failure to grant exemptions may have a discriminatory impact on believers, ${ }^{93}$ he nonetheless concludes that such de facto discrimination is preferable to the harm caused by granting exemptions. ${ }^{94}$ Thus, unlike McConnell or Kurland, Marshall acknowledges that his solution requires at least some subordination of one religion clause to the other.

Scholars have also made parallel argnments on each side questioning the very framing of the question as one of "discrimination." McConnell has suggested that the Free Exercise Clause provides not only protection against religious discrimination, but also a substantive right to religious liberty. ${ }^{95} \mathrm{He}$ can therefore argue that the real evil of a generally applicable law is not its discriminatory effect

\footnotetext{
${ }^{90}$ Laycock's characterization of the Court's view of what it accomplished by not granting exemptions is perhaps the most telling. He notes that the Court believes that "religious minorities will give up their faith without a fuss if the law says they must." Laycock, Remnants at 29. In fact, as Laycock points out, for some believers this is incorrect. Although Laycock is surely right as far as he goes, it is probably also incorrect to assume that all secular objectors-especially those whose objections are principled and morally, politically, or philosophically based-will give up their beliefs easily. The many secular objectors to draft laws and Jim Crow laws who went to jail rather than obey are evidence that religious believers do not have a monopoly on martyrdom.

${ }^{91}$ Marshall, In Defense of Smith (cited in note 64).

${ }^{92}$ See Part III.

${ }^{93}$ Id at 318.

${ }^{94}$ Id at 318-19.

${ }^{95}$ Michael W. McConnell, Free Exercise Revisionism and tbe Smith Decision, 57 U Chi L Rev 1109,1137 (1990). Even this formulation may not lead McConnell where he wants to go. It is not so clear that a law that unintentionally and indirectly infringes a constitutionally protected right is unconstitutional. For example, a law that indirectly (and purportedly unintentionally) infringes freedom of speech is not tested by strict scrutiny but by a less rigorous standard. See, e.g., US v O'Brien, 391 US 367 (1968). Similarly, refusing to fund abortion-analogous to refusing to exempt religious practices from general laws-does not violate the constitutional right to abortion, Harris $v$ McRae, 448 US 297 (2980), even though it may have a detrimental effect on individual exercise of the underlying constitutional right.
} 
on religious objectors but its infringement of their right to practice their religion. A similar gambit also can be made on the other side, however. Kathleen Sullivan has suggested that the Establishment Clause creates an analogous substantive right: the right to a "civil order for the resolution of public moral disputes."96 Thus, whereas McConnell claims that religious adherents have a right to practice their religion, Sullivan claims that non-adherents have a right to a secular government. This merely reframes the discrimination issue in terms of conflicting substantive rights: any governmental accommodation of the right to practice one's religion necessarily infringes the right to a secular government (and vice versa).

These parallel recharacterizations yield an important observation. The gist of my argument is that it is not possible simultaneously to implement the core values of both religion clauses. By framing the question in terms of substantive rights, McConnell and Sullivan highlight an issue underlying the work of all the scholars I have discussed: what is the "true meaning" of the religion clauses? In response to my arguments, McConnell can claim that a narrow (or redundant) reading of the Establishment Clause is correct; Kurland, on the other hand, can claim that a narrow (or redundant) reading of the Free Exercise Clause is correct. Unfortunately, in their haste to reconcile the two clauses without subordinating either, neither they nor anyone else has seriously justified the choice of which clause to interpret narrowly and which to interpret broadly.

McConnell has argued that the founding generation intended a narrow reading of the Establishment Clause. ${ }^{97}$ But beyond being subject to all the objections to originalism generally, ${ }^{98} \mathrm{McC}$ Connell's history is itself controversial in its details. ${ }^{99}$ Moreover, it is at least plausible that the founding generation intended broad readings of both clauses, without realizing that in our highly regulated and

${ }^{96}$ Kathleen M. Sullivan, Religion and Liberal Democracy, 59 U Chi L Rev 195, 197 (1992).

${ }^{97}$ Michael W. McConnell, The Origins and Historical Understanding of Free Exercise of Religion, 103 Harv L Rev 1409 (1990).

${ }^{98}$ See generally Daniel A. Farber, The Originalism Debate: $A$ Guide for the Perplexed, 49 Ohio St L J 1085 (1989).

99 Compare Micbael W. McConnell, Coercion: The Lost Element of Establisbment, $27 \mathrm{Wm} \&$ Mary L Rev 933 (1986), with Douglas Laycock, "Noncoercive" Support for Religion: Anotber False Claim about tbe Establisbment Clause, 26 Valp U L Rev 37 (1991); and Lee v Weisman, $112 \mathrm{~S} \mathrm{Ct}$ at 2672-76 (Souter, J, concurring). 
subsidized society the two would often conflict. ${ }^{100}$ Thus, religious believers in an era of truly limited government could quite reasonably press for the adoption of both clauses, in order to keep government from interfering with religious belief either positively or negatively, without foreseeing that one day a government policy that kept its distance from religion by not singling it out for special treatment in either direction might itself constitute an interference with religion.

Laycock has suggested an alternative justification for his preferred reading of the clauses. He says it would be "implausible" to adopt a reading of the Free Exercise Clause that would allow (or require) government to prohibit the religious use of wine if it prohibited alcohol consumption generally. ${ }^{101}$ It is not implausible from a historical perspective, as the founding generation had no idea that government might be so involved in the lives of the people as to prohibit ordinary, everyday practices that affect religion. Advocates of the religion clauses feared deliberate persecution, not unforeseen general government growth with a negative impact on religion. ${ }^{102}$ And it is only implausible from a practical perspective if one values religious celebrations more than non-religious onesbringing us back to the issues of perspective and differentiation.

The main purpose of this essay is to suggest that what is needed is a persuasive justification for preferring one clause to the other. Rather than denying the subordinating effects of their "reconcilia-

${ }^{100}$ Robert Bork has made a similar observation about the Equal Protection Clause, suggesting that the Reconstruction architects' simultaneous desire for equality and for segregation made sense to them but cannot be implemented today. Robert Bork, The Tempting of America: The Political Seduction of tbe Law 74-84 (Macmillan 1990).

${ }^{101}$ Laycock, Neutrality at 1000-1001 (cited in note 54).

${ }^{102} \mathrm{McC}$ Connell bases his contrary historical conclusion on weak evidence. For example, he interprets Madison's original draft prohibiting the infringement of rights of conscience "on any pretext" as prohibiting infringement "for any reason," including unintentionally. McConnell, Update at 691 n 25 (cited in note 54). The more usual reading of "pretext," however, suggests an intentional act with a disguised motivation. Madison was guarding against intentional discrimination disguised as neutrality, not truly general laws enacted for nondiscriminatory reasons. The normal meaning of "pretext" is apparent in John Marshall's use of the term some years later in McCulloch v Maryland, 4 Wheaton 316, 423 (1819).

There is also some evidence that those who drafted the Bill of Rights specifically did not intend to require accommodation. Egbert Benson of New York, for example, moved to strike language requiring a military exemption for conscientious objectors on the ground that "[n]o man can claim this indulgence of right. It may be a religious persuasion, but it is no natural right, and therefore ought to be left to the discretion of the Government." I Annals of Cong. 751 (Joseph Gales ed., Washington, Gales \& Seaton 1834) (Aug. 17, 1789). 
tions," religion clause scholars might more constructively recognize the problem and attempt more forthrightly to justify their preferences for one clause over the other. What purposes does religion serve in a modern democracy, and how should we best foster those goals? Much of modern constitutional scholarship in other areas has focused on similar questions, but religion clause jurisprudence has been mired in attempts to reconcile the irreconcilable. The time has come to admit the conflict and to make an honest choice. ${ }^{103}$

Whether the issue is coercion or discrimination, we cannot escape the conclusion that anything we do with regard to exemptions harms someone in a constitutionally significant way. The scholars who subordinate the Free Exercise Clause recognize what McConnell and others overlook: that granting an exemption sends a message of endorsement of religious over secular beliefs and relegates nonbelievers to the status of outsiders. Ironically, those very same scholars fail to recognize that the failure to exempt religious believers from regulations that indirectly but severely burden religious practice has a similar effect on believers, relegating them to the status of outsiders whose fundamental beliefs are not respected by

${ }^{103}$ Justice Blackmun has suggested a different "reconciliation" that deserves brief comment. In Bullock, he suggested that while a special tax exemption for religious publications violated the Establishment Clause, failure to exempt such publications might violate the Free Exercise Clause. He proposed that perhaps the Court should therefore require the state to broaden its exemption to include secular literature devoted to similarly philosophical questions. 489 US at $27-28$.

Blackmun's approach is similar to the approach taken in other discriminatory effect contexts. The usual rule under Title VII, for example, is that where a particular employment practice has a discriminatory effect on a protected group, the employer is prohibited from applying the practice either to that group or to any similarly situated non-minority employees.

Unfortunately, any attempt to implement such an approach in the religion context would be highly impractical. The Court has used this approach in determining the scope of conscientious objector status, concluding that such status must be granted to anyone whose objection to military service is equivalent to a religious objection. See Welsb v United States, 398 US 333 (1970); United States $v$ Seeger, 380 US 163 (1965). The case-by-case determination required by that rule, however, severely reduced the efficiency of the selective service process, and the whole process ultimately favored primarily upper middle class whites. See, e.g., Lawrence M. Baskir \& William A. Strauss, Cbance and Circumstance: Tbe Draft, tbe War and tbe Vietnam Generation 7-9, 41-42 (Knopf 1978). To extend such a process to every claim of objection to ordinary laws would be likely to affect both efficiency and neutrality in the same way but on a more massive scale.

Moreover, if any serious (non-frivolous) objection to a law led the courts to require a compelling interest in the law, either many laws would be invalidated or the compelling interest test would be drastically diluted. That dilution would in turn probably affect the application of strict scrutiny in other constitutional contexts. 
the majority. The choice between these alternatives is not easy, but we cannot make it disappear by denying the hardship that each alternative causes.

\section{The Court's Resolution: Paradox Redux}

In 1990, the Court finally resolved the paradox in one of the two possible ways. In Employment Division $v$ Smith, ${ }^{104}$ it abandoned the Yoder-Sberbert line of cases (confining them to their facts) and announced that henceforth religious objectors had the same obligation to obey neutral laws as everyone else. Assuming that Lemon would still govern establishment cases, Smitb's repudiation of the exemption doctrine yielded a consistent jurisprudence that coupled a narrow interpretation of the Free Exercise Clause with a broad interpretation of the Establishment Clause. Although immediately attacked by most commentators, ${ }^{105}$ Smith was the first glimmer of coherence in the Court's religion clause jurisprudence in twenty years.

As I have argued, there were only two ways for the Court to resolve the tension created by its broad interpretation of both the religion clauses - either to narrow its construction of the Establishment Clause or to narrow its view of the Free Exercise Clause. Although some might quarrel with the Court's decision to choose the latter course, one or the other was necessary. Which course one prefers depends on which clause one thinks more important, ${ }^{106}$ but the burden of my argument has been to show that one of these two choices was essential. Despite the many failed efforts at "reconciliation," no one has yet persuasively justified choosing one

${ }^{104} 494$ US 872 (1990). The result in Smith was presaged in a series of cases in which the Court seriously watered down the Yoder test in order to deny exemptions in a variety of situations, see, e.g., Jimmy Swaggart Ministries v Board of Equalization, 493 US 378 (1990); Lyng v Nortbwest Indian Cemetery Prot. Ass'n, 485 US 439 (1988); Tony \& Susan Alamo Foundation v Secretary of Labor, 471 US 290 (1985), or interpreted legislatively granted exemptions so narrowly as to render them almost trivial, see, e.g., Ansonia Board of Education v Pbilbrook, 479 US 60 (1986).

${ }^{105}$ See, e.g., sources cited in Lupu, Rcconstructing the Establishment Clause, $140 \mathrm{U}$ Pa L Rev at $561 \mathrm{n} 13$.

${ }^{106}$ This is not to say that it is necessarily a matter of pure personal preference, of course. Different theoretical approaches to constitutional analysis would yield different answers to the question of which clause is more important. My point in the text is that since scholars seem to have concentrated largely on "reconciling" the two clauses, there is little or no scholarship considering why one clause or the other ought to be deemed superior. 
clause over the other, and only such an argument could meaningfully defend or criticize Smith on its merits. In the absence of any persuasive reason to prefer one clause over the other, Smith remains defensible as one of two equally valid positions, and one that is clearly more coherent than the hopelessly conflicted prior state of affairs.

Although it resolved the paradox, however, Smith contained the seeds of an equally problematic conflict, which came to fruition only two years later in Lee $v$ Weisman. Although the Court in Smitb held that exemptions for religious objectors are not constitutionally required, it also suggested that such exemptions are not prohibited if a legislature chooses to grant them. Thus, at the same time that the Court narrowed its interpretation of the Free Exercise Clause, it intimated that it was on the verge of narrowing its interpretation of the Establishment Clause as well. In Lee $v$ Weisman it did just that, unofficially abandoning Lemon for its much narrower coercion test. ${ }^{107}$

Thus, the brief but coherent reign of a narrow free exercise jurisprudence and a broad establishment jurisprudence was almost immediately replaced by narrow interpretations of both clauses. In the context of exemptions, this means that exemptions are routinely permitted, but never constitutionally required. In its own way, this creates a paradox as puzzling as-and more troubling than-its predecessor.

The problem with the Court's current interpretation is that it leaves both clauses without substantive content, for no apparent reason. No theory of the underlying values of the religion clauseswhether neutrality, benevolence, or separationism-justifies a scheme in which the government is permitted but not required to grant exemptions. ${ }^{108}$ Permitting the legislature broad leeway to grant exemptions suggests that the purpose of the religion clauses

${ }^{107}$ In particular, it is clear that exemptions will be permitted even though they are not required. Even Justice Souter, who with Justices Stevens and O'Connor rejected the coercion test in favor of an "endorsement" test, thought legislative accommodation of religious practices would be permissible. Lee $v$ Weisman, $112 \mathrm{~S} \mathrm{Ct}$ at 2676-77 (Souter, J, concurring).

${ }^{108}$ Mark Tushnet has argued that the "disarray" of the religion clauses stems from our abandonment of our republican heritage in favor of a purely liberal world. Mark V. Tushnet, Red, Wbite and Blue: A Critical Analysis of Constitutional Law 247-76 (Harvard 1988). Although he wrote before either Smitb or Weisman, his explanation could apply equally well to today's religion clauses. 
is, as McConnell suggests, to protect and nurture individual religious beliefs in the face of governmental pressure to conform, thus elevating free exercise values. But if that is the case, the clauses should also be read to require exemptions in circumstances where the pressure to conform is great and the need for conformity is minimal. Similarly, if - as the holding in Smith seems to suggestthe purpose of the religion clauses is to allow a secular government to operate independent of the varied religious beliefs of the citizenry, thus elevating Establishment Clause values, then accommodation of religion at the expense of non-religion must be forbidden in order to preserve that independence. For the Court generally to permit but not to require exemptions achieves no goal that can be explained by reference to any possible purpose of the religion clauses.

Moreover, the practical result of simultaneously narrow interpretations of both clauses is even worse than the result of the earlier conflict caused by the Court's broad interpretation of both clauses. Recall that under the Yoder-Lemon scheme the Court was effectively empowered to choose among religions, deciding which deserved exemptions and which did not. Under the current scheme, that same unfettered discretion is accorded the legislature. All religious accommodation is now "a matter of political discretion, rather than a matter of constitutional right." 109 The decision whether to grant or withhold exemptions will now reflect the religious preference of the majority, thus compounding the "bias in favor of mainstream over non-mainstream religions." 110 As a general rule, courts will be more evenhanded than legislatures, since they are "sworn to do equal justice to all . . . and to treat like cases alike." Legislatures, on the other hand, "are [constitutionally] free to reflect majority prejudices, to respond to the squeakiest wheel among minorities, to trade votes and make compromises, and to ignore problems that have no votes in them."11

This is the worst of all possible "solutions," for neither equal accommodation of religion nor equal indifference to religion is

\footnotetext{
${ }^{109}$ Lupu, Reconstructing the Establishment Clause, $140 \mathrm{U}$ Pa L Rev at 573 (cited in note 82).

${ }^{110}$ McConnell, Crossroads at 139 (cited in note 34). See also Mark Tushnet, "Of Cburcb and State and the Supreme Court": Kurland Revisited, 1989 Supreme Court Review 373, 386-87.

"' Laycock, Rcmnants, 1990 Supreme Court Review at 15 (cited in note 69). See also Lupu, Reconstructing the Establisbment Clause, $140 \mathrm{U} \mathrm{Pa} \mathrm{L} \mathrm{Rev} \mathrm{at} \mathrm{600-606} \mathrm{(cited} \mathrm{in} \mathrm{note} \mathrm{82).}$
} 
mandated. Instead, an unrestrained majority is authorized to indulge its discriminatory preferences. ${ }^{12}$ Despite the breadth of solutions offered by the various scholars discussed in this article, those scholars are almost unanimous in their condemnation of this particular scheme. ${ }^{113}$ It is both tragic and ironic that the Court has moved toward a construction of the religion clauses that serves none of the possible underlying goals of First Amendment and that replaces a regime that encourages judicial incoherence with one that encourages legislative intolerance.

112 Even McConnell appears to concede that Smitb's abandonment of required exemptions would be better paired with a broad Establishment Clause-which at least would strike down discriminatory accommodations by the legislature-than with a narrow one. McConnell, Free Exercise Revisionism, $57 \mathrm{U}$ Chi L Rev at 1132 (cited in note 95). McConnell may have revised his position, as he has more recently suggested that legislatures are competent to make accommodation choices. McConnell, Update at 722-26 (cited in note 54).

113 The only exception appears to be William Marshall, who applauds the Court's adoption of a rule of permissive but not required exemptions. See Marshall, In Defense of Smith, espec. p. 323 (cited in note 64). Marshall's main thrust in this short article, however, is to defend the more narrow holding of Sinitb-that exemptions are not required by the Free Exercise Clause-and his discussion of permissive exemptions focuses primarily on how they are constitutionally distinguishable from mandatory exemptions. Thus he offers no real defense of the general scheme of permitting but not requiring exemptions. 
HeinOnline -- 1992 Sup. Ct. Rev. 1541992 